\title{
Neuronal Migration Protein Doublecortin
}

National Cancer Institute

\section{Source}

National Cancer Institute. Neuronal Migration Protein Doublecortin. NCI Thesaurus.

Code C75322.

Neuronal migration protein doublecortin (402 aa, $\sim 45 \mathrm{kDa}$ ) is encoded by the human DCX gene. This protein is involved in neuronal migration. 